\begin{tabular}{cc|c}
\hline Tar. Bil. Der. & Tarım Bilimleri Dergisi & Journal of Agricultural Sciences \\
& $\begin{array}{c}\text { Dergi web sayfası: } \\
\text { www.agri.ankara.edu.tr/dergi }\end{array}$ & Journal homepage: \\
& www.agri.ankara.edu.tr/journal
\end{tabular}

\title{
Mass Balance Criteria in Soil Salinity Management: Different Irrigation Water Qualities and Leaching Ratio
}

\author{
Engin YURTSEVENa ${ }^{a}$, Hasan Sabri ÖZTÜRK ${ }^{\mathrm{b}}$, Sertan AVCI ${ }^{\mathrm{a}}$ \\ a Ankara University, Faculty of Agriculture, Department of Farm Structures and Irrigation, Ankara, TURKEY

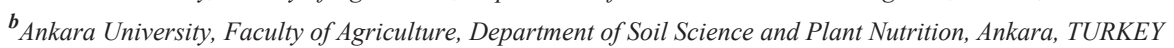

\section{ARTICLE INFO}

Research Article

DOI: 10.1501/Tarimbil 0000001270

Corresponding Author: Engin YURTSEVEN, E-mail: yurtsev@ankara.edu.tr, Tel: +90 (312) 5961208

Received: 21 August 2013, Received in Revised Form: 23 December 2013, Accepted: 8 January 2014

\begin{abstract}
The accumulation of excess soluble salts in the root zone of arid and semiarid irrigated soils is a widespread problem that seriously affects crop productivity. The cultivated soil profile under irrigation is the main media in which the salinization occurs. In this study, the effects of different irrigation water salinity and leaching ratio on soil profile salt mass balance changes were investigated in alfalfa (Medicago sativa L.) cultivated PVC lysimeters ( $115 \mathrm{~cm}$ in height and $40 \mathrm{~cm}$ diameter). Three irrigation water salinity $\left(\mathrm{S}_{1}, \mathrm{~S}_{2}\right.$, and $\mathrm{S}_{3}, 0.25,1.5$ and $3.0 \mathrm{dS} \mathrm{m}^{-1}$, respectively) and four leaching ratios, $\mathrm{LF},(10 \%, 20 \%, 35 \%$ and $50 \%$ more water than $\mathrm{ET})$ levels were used in a fully randomized factorial design experiment with three replications. The total salt mass balance was calculated from the subtraction of total salt mass concentration supplied with irrigation water and total salt mass concentration washed out with the drainage water. When the salinity content of irrigation water increased leaching of $\mathrm{SO}_{4}^{2-}$ and $\mathrm{Cl}^{-}$accumulation in the soil increased. Increase in the leaching ratio (LF) caused increase in the leaching of $\mathrm{Cl}^{-}$through the soil profile. The major cations, $\mathrm{Ca}^{2+}, \mathrm{Mg}^{2+}$, and $\mathrm{Na}^{+}$, in the soil were also evaluated for their total mass concentrations regarding salinity content of irrigation water and LF. $\mathrm{Ca}^{2+}$ concentration in the soil profile increased with salinity level and the leaching ratio, whereas $\mathrm{Mg}^{2+}$ and $\mathrm{Na}^{+}$mass concentrations decreased considerably. This is due to the high $\mathrm{Ca}^{2+}$ adsorption in the soil than that of $\mathrm{Na}^{+}$. The effect of LF on the ion mass accumulation or leaching varied depending on the ion type.
\end{abstract}

Keywords: Solute transport; Leaching; Soil salinity; Soil mass balance; Column experiment

\section{Toprak Tuzluluğu Yönetiminde Tuz Dengesi Kavramı: Farklı Sulama Suyu Tuzluluğu ve Yıkama Oranı}

\section{ESER BILLGÍsí}

Araştırma Makalesi

Sorumlu Yazar: Engin YURTSEVEN, E-posta: yurtsev@ankara.edu.tr, Tel: +90 (312) 5961208

Geliş Tarihi: 21 Ağustos 2013, Düzeltmelerin Gelişi: 23 Aralık 2013, Kabul: 8 Ocak 2014

\section{ÖZET}

Kurak ve yarı-kurak alanlarda toprakta biriken fazla tuzlar yaygın bir sorun olarak karşımıza çıkmaktadır. Tarım alanlarında tuzlulaşmanın meydana geldiği temel ortam sulanan alanlardır. Bu çalışmada, farklı sulama suyu tuzluluğu ve 
yıkama oranlarının toprak profilindeki tuz dengesine olan etkileri, yonca (Medicago sativa L.) yetiştirilen PVC kolonlarda ( $115 \mathrm{~cm}$ uzunluğunda ve $40 \mathrm{~cm}$ çapında) incelenmiştir. Çalışmada 3 sulama suyu tuzluluğu $\left(0.25,1.5 \mathrm{ve} 3 \mathrm{dS} \mathrm{m}^{-1}\right.$ sırasıyla $\mathrm{S}_{1}, \mathrm{~S}_{2}$, and $\mathrm{S}_{3}$ ) ve 4 yıkama oranı (gereğinden $\% 10,20,35$ ve 50 daha fazla sulama suyu) konuları 3 tekrarlamalı olarak tesadüf parsellerinde faktöriyel deneme şeklinde denenmiştir. Profildeki tuz dengesi, sulama suyu ile sağlanan toplam tuz miktarından, drenaj suyu ile dışarı atılan miktarın farkından hesaplanmıştır. Sulama suyunun tuz içeriği artıkça, fazla miktardaki $\mathrm{Cl}^{-}$nedeniyle topraktan $\mathrm{SO}_{4}^{2-}$ yıkanması artmış ancak $\mathrm{HCO}_{3}^{-}$artmamıştır. Çözünebilir anyonlardan $\mathrm{SO}_{4}^{2-}$ profilden yıkanırken $\mathrm{Cl}^{-}$, sulama suyu tuzluluğunun artmasına bağlı olarak birikmiştir. Yıkama oranının artması toprak profildeki $\mathrm{Cl}^{-}$yıkanmasına neden olmuştur. Toplam tuz dengesi, topraktaki başat katyonlar için de $\left(\mathrm{Ca}^{2+}, \mathrm{Mg}^{2+}, \mathrm{ve} \mathrm{Na}^{+}\right)$ sulama suyunun tuz konsantrasyonu ve yıkama oranına göre değerlendirilmiştir. Toprak profilindeki $\mathrm{Ca}^{2+}$ miktarı sulama suyu tuzluluğu ve yıkama oranlarına bağlı olarak artma gösterirken, $\mathrm{Mg}^{2+}$ ve $\mathrm{Na}^{+}$dengesi önemli bir şekilde azalmıştır. $\mathrm{Bu} \mathrm{Ca}^{2+}$ 'un $\mathrm{Na}^{+}$' a göre toprakta daha fazla tutulması nedeniyledir. Genelde yıkama oranlarının tuz dengesi üzerine etkisi iyonlara bağlı olarak değişiklik göstermektedir.

Anahtar Kelimeler: Çözelti hareketi; Yıkama; Toprak tuzluluğu; Toprak tuz dengesi; Kolon denemesi

(C) Ankara Üniversitesi Ziraat Fakültesi

\section{Introduction}

Increasing pressure on agricultural food production in semiarid areas forces the farmers use marginal quality of irrigation water. On the other hand, irrigation solely guarantees sustainable production in such area. After using low quality irrigation water for many years, soil salinization, ultimately, has become the key factor challenging sustainability.

Irrigation has long played a key role to produce food, feed, and fiber to meet the needs of the expanding world population (Oster et al 2012). The water scarcity and some other problems such as water-logging, salinization, and soil and water quality degradation are threatened the future of irrigated agriculture. For sustainable irrigation, innovative and more efficient agricultural water management development is required. Particularly, avoiding of some applications as disposing of saline drainage waters into surface waters or onto lands is a primary event of salinization and soil and water quality degradation (Skaggs et al 2006).

Water is an essential element in one's life by sustaining the economic development and growth. Therefore, anywhere in the world sustainability of maintaining a safe and dependable water supply would be more important (Hutson \& Ickert 2012).

The excess soluble salts accumulated in the root zone of arid and semiarid irrigated soils is a common problem that seriously affects crop productivity all around the world. According to Corwin et al (2007) the evapotranspiration is the essential mechanism causing the accumulation of salt in the soil, to be concentrated salts in the remaining soil water. Soil salinity affects plants in different ways; loss of stand, reduced plant growth and yield, and even worst crop failure. Salinity reduce plant water uptake by increasing the osmotic pressure so it would more difficult for the plant to extract water. Excessive concentrations of some specific ions may also cause ion toxicity or spoil the nutritional balance of plants.

A considerable part of world's total food and fiber $(35-40 \%)$ in encountered from the irrigated agriculture, and all around the world, roughly half of all irrigated soils is affected by soil salinity, and almost 20 million ha of this amount is heavily affected by salinity (Rhoades \& Loveday 1990). To prevent the accumulation of excessive soluble salts in irrigated soils, more water than required to meet the evapotranspiration needs of the crops must pass through the root zone to leach excessive soluble salts. This additional irrigation water has typically been expressed as the leaching requirement (LR) (Richards 1954; Rhoades 1974).

The total ion concentration leached out from the soil profile is strictly dependent on the leaching water amount applied and the management practices of the LR. The remain concentration of soluble salts after leaching water passed through the soil profile, caused soil salinity at the end of the irrigation 
period. The differentiation of the total concentration leached and total concentration added also with the irrigation water, called mass balance and resulted the total salt remaining in the soil profile. Added and leached salt concentrations are being calculated by using the soluble salt concentrations of the irrigation water and drainage water, which is passed through the soil profile and leached ions from the profile (Richards 1954; Zhong 2011). The plant uptake of the salt constituents such as $\mathrm{Na}^{+}, \mathrm{Ca}^{2+}$, $\mathrm{Mg}^{2+}$, generally are not taken into consideration but, might be important amount of uptake by the plants (Zhong 2011). And different salinity constituents play different role to be uptaken by plants; While some of them $\left(\mathrm{Mn}, \mathrm{Na}^{+}\right)$could be taken easily, some $\left(\mathrm{K}^{+}, \mathrm{Mg}^{2+}\right)$ are not (Al-Absi et al 2009). Y1ldız \& Terzi (2011) researched twelve cultivars of barley (Hordeum vulgare L.) subjected to different $\mathrm{NaCl}$ concentrations and classified according to their salt tolerance at early seedling stage.

In this study, the total mass balance calculated using the differentiation of the total ion concentration that entering into the soil profile with the irrigation water and leached out from the profile with drainage water which is the water percolated and went out from the end point of the soil columns. During the calculation the ion concentration used by the crop roots by taking them into the body is neglected.

\section{Material and Methods}

The outdoor lysimeter system used in this study located at the experimental field of Ankara University, Ankara, Turkey. The experiments were conducted in PVC lysimeters $(115 \mathrm{~cm}$ in height and $40 \mathrm{~cm}$ in diameter) cultivated with alfalfa (Medicago sativa $\mathrm{L}$.). The soil used was taken from the experimental field, sieved from $2 \mathrm{~mm}$ sieve and filled up homogenously for all the columns considering their original bulk density. The physical and chemical characteristics of the soil are given in Table 1.

The soil texture is sandy clay loam with the bulk density of $1.31 \mathrm{~g} \mathrm{~cm}^{-3}$. The soil was irrigated ten times in the first year and six for the second year. The drainage water samples were collected just after the irrigation applications as the leaching volume from the cups located under each column.

For the lyzimeter experiments, three irrigation water salinity $\left(\mathrm{S}_{1}, \mathrm{~S}_{2}\right.$, and $\mathrm{S}_{3}, 0.25,1.5$ and $3.0 \mathrm{dS} \mathrm{m} \mathrm{m}^{-1}$, respectively) and four leaching fraction treatment $\left(\mathrm{LF}_{1}, \mathrm{LF}_{2}, \mathrm{LF}_{3}\right.$ and $\mathrm{LF}_{4}, 10,20,35$ and $50 \%$ more irrigation water than required for evapotranspiration, respectively) levels, as a fully randomized design experiment were used with three replication. For artificial salinization of the irrigation water, $\mathrm{NaCl}$ and $\mathrm{CaCl}_{2}$ salts were added in the tap water considering the SAR less than 1. The properties of irrigation waters used in the experiments are given in Table 2 .

Table 1- Some physical and chemical characteristics of soil

Çizelge 1- Topră̆ın bazı fiziksel ve kimyasal özellikleri

\begin{tabular}{cccccccccc}
\hline \multirow{2}{*}{$\mathrm{H}$} & $\begin{array}{c}E C \\
\left.(\mathrm{dS} \mathrm{m})^{-1}\right)\end{array}$ & $\begin{array}{c}\text { Bulk density } \\
\left(\mathrm{g} \mathrm{cm}^{-3}\right)\end{array}$ & $\begin{array}{c}\text { Field capacity } \\
(\%)\end{array}$ & $\begin{array}{c}\text { Wilting point } \\
(\%)\end{array}$ & $\begin{array}{c}\text { Organic matter } \\
(\%)\end{array}$ & $\begin{array}{c}\text { Sand } \\
(\%)\end{array}$ & $\begin{array}{c}\text { Silt } \\
(\%)\end{array}$ & $\begin{array}{c}\text { Clay } \\
(\%)\end{array}$ & $\begin{array}{c}\text { Texture } \\
(\%\end{array}$ \\
\hline 8.18 & 0.816 & 1.310 & 23.06 & 17.38 & 1.33 & 58 & 21 & 21 & $\mathrm{SCL}^{2}$ \\
$\mathrm{Na}^{+*}$ & $\mathrm{Ca}^{2+*}$ & $\mathrm{Mg}^{2+*}$ & $\mathrm{~K}^{+*}$ & Total & $\mathrm{SO}_{4}^{2-*}$ & $\mathrm{CO}_{3}^{2-*}$ & $\mathrm{HCO}_{3}^{-*}$ & $\mathrm{Cl}^{-*}$ & $\mathrm{Total}^{*}$ \\
1.48 & 4.9 & 2.26 & 0.28 & 8.92 & 3.05 & 4.59 & 1.28 & 8.92 \\
\hline
\end{tabular}

*, unit is mmol $_{\mathrm{c}} \mathrm{L}^{-1}$

Table 2- The average ion concentrations of the irrigation waters used $\left(\mathrm{mmol}_{\mathrm{c}} \mathrm{L}^{-1}\right)$

Çizelge 2- Denemelerde kullanılan sulama sularının ortalama iyon konsantrasyonları $\left(\right.$ mmol $\left._{c} L^{-1}\right)$

\begin{tabular}{cllllllllllll}
\hline Treatmentsts & $\mathrm{Cl}$ & $\mathrm{NO}_{2}^{2-}$ & $\mathrm{NO}_{3}^{-}$ & $\mathrm{SO}_{4}^{-2}$ & $\mathrm{CO}_{3}^{2-}$ & $\mathrm{HCO}_{3}^{-}$ & Total & $\mathrm{Na}^{+}$ & $\mathrm{K}^{+}$ & $\mathrm{Mg}^{2+}$ & $\mathrm{Ca}^{2+}$ & $\mathrm{Total}^{2}$ \\
\hline $\mathrm{S}_{1}$ & 0.50 & 0.00 & 0.00 & 0.24 & 0.00 & 1.60 & 2.34 & 0.43 & 0.07 & 1.14 & 0.70 & 2.34 \\
$\mathrm{~S}_{2}$ & 13.08 & 0.00 & 0.00 & 0.35 & 0.00 & 1.90 & 15.52 & 1.94 & 0.04 & 0.56 & 13.24 & 15.79 \\
$\mathrm{~S}_{3}$ & 27.74 & 0.00 & 0.00 & 0.37 & 0.00 & 1.90 & 30.20 & 3.56 & 0.05 & 0.57 & 26.12 & 30.29 \\
\hline
\end{tabular}

Tarım Bilimleri Dergisi - Journal of Agricultural Sciences 20 (2014) 103-111 
The irrigation water requirement was determined according to TDR measurements, and soil samples. The TDR measurements were taken only from the burial probes placed in the center block of the experiment, while the soil samples for soil moisture measurement were taken from the two spare lysimeters irrigated with the $\mathrm{S}_{1}$ water.

The amount of irrigation water to bring the moisture content to its field capacity $(-33 \mathrm{kPa})$ was calculated and, later, it was multiplicated by 1.1, 1.2, 1.35, and 1.5 for the $\mathrm{LF}_{1}, \mathrm{LF}_{2}, \mathrm{LF}_{3}$ and $\mathrm{LF}_{4}$ treatments, respectively. Experimental columns were irrigated with drip irrigation system.

After each irrigation, drainage water samples were collected from the bottom part of the lyzimeters and soil samples were taken each every $20 \mathrm{~cm}$ up to $100 \mathrm{~cm}$ depth. Salinity constituents (electrical conductivity, $\mathrm{pH}, \mathrm{Na}^{+}, \mathrm{K}^{+}, \mathrm{Ca}^{2+}, \mathrm{Mg}^{2+}, \mathrm{SO}_{4}^{2-}, \mathrm{HCO}_{3}^{-}$, and $\mathrm{Cl}^{-}$) were determined. Total salinity (EC), was determined by the procedures described by Richards (1954), in $25{ }^{\circ} \mathrm{C}$, with electrical conductivity instrument (YSI 3000). Laboratory measurement of $\mathrm{pH}$ was made with glass electrode $\mathrm{pH}$ meter (Martini Mi 151). All the cation and anion analysis were performed by ion chromatography system (Dionex ICS 1600).

The formula for calculating the leaching ratio values was the simple leaching fraction LF equation given by Richards (1954);

$L F=\frac{D_{d w}}{D_{i w}}$

Where; $\mathrm{D}_{\mathrm{dw}}$, drainage water amount; and $\mathrm{D}_{\mathrm{iw}}$, total irrigation water amounts in liter.

The mass balance of the salinity constituents was calculated as a differentiation of the total ion mass concentration supplied with irrigation water, and the total ion mass concentration that leached from the soil with drainage water, neglecting the plant ion extraction from the soil profile.

The soil mass balance (SMB) formula is;

$$
S M B=\left[\left(C_{i w} \times D_{i w}\right)-\left(C_{d w} \times D_{d w}\right)\right]
$$

Where; $\mathrm{C}_{\mathrm{iw}}$ and $\mathrm{C}_{\mathrm{dw}}$ are the ion concentrations of irrigation and drainage water; $\mathrm{D}_{\mathrm{iw}}$ and $\mathrm{D}_{\mathrm{dw}}$ are the total irrigation and the total drainage water amounts, respectively.

Ion concentration and total water amount were considered as $\mathrm{mmol}_{\mathrm{c}} \mathrm{L}^{-1}$, and liters respectively. According to SMB, the soil profile was considered as salinized when the results were positive, or leached out from the salinity constituents when the results were negative. So the accumulation or leaching phenomena was evaluated. In this study, the total mass balances were calculated for the major salinity constituents of $\mathrm{Na}^{+}, \mathrm{Ca}^{2+}, \mathrm{Mg}^{2+}, \mathrm{SO}_{4}{ }^{2-}, \mathrm{NO}^{3-}, \mathrm{HCO}_{3}^{-}$, and $\mathrm{Cl}^{-}$individually.

\section{Results and Discussion}

Figure 1 shows the total amount of drainage water and the calculated leaching fractions for the leaching treatments, as average replications for both years. The leaching ratios were $11,15,18$, and $20 \%$ for the first year, and $7,15,21$, and $25 \%$ for the second year. The materialized LF ratios were different that the theoretical ones. The reasons for that is unequal distribution of the irrigation water through soil surface, the way of calculation of the amount of irrigation water and the difference the salinity level of the columns.

The SMBs were calculated using Equation (2) for all the main exchangeable ions in the drainage water and the results are shown in Figure 2 and 3. The entering salts were considered the ones which came into the soil with irrigation water, and the exiting salts were those leached out with drainage water. The SAR of the soil was not well correlated with neither irrigation water salinity nor LF. It means that the SAR values did not change significantly with the variation of the irrigation water salinity and the leaching ratios.

\subsection{SMB for anions}

The SMB variations and the correlation coefficients of the major anions $\mathrm{SO}_{4}^{2-}, \mathrm{HCO}^{-3}$ and $\mathrm{Cl}^{-}$among the treatments are given in Figure 2 for both years. Figure 2 shows that the leaching of $\mathrm{SO}_{4}^{2-}$ increased 


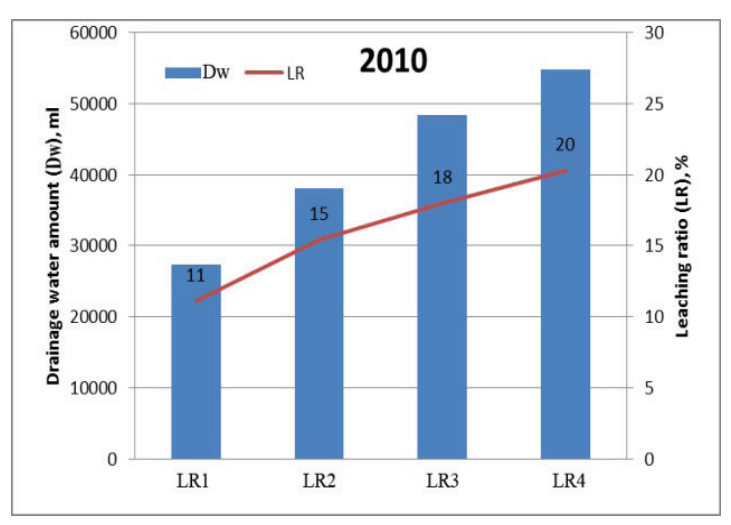

2010

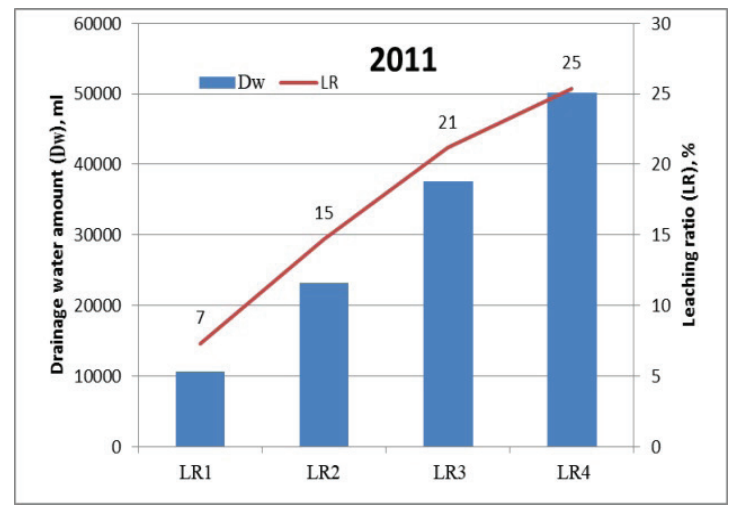

2011

Figure 1- Total measured drainage water $\left(D_{w}\right)$ amounts and accrued leaching ratios $(\mathrm{LR})$ for the leaching treatments

Şekil 1- Yıkama konuları için ölçülen drenaj suyu toplamları $\left(D_{w}\right)$ ve gerçekleşen yıkama oranları (LR)

with the leaching rate for all the salinity levels of irrigation water. Most of the soluble $\mathrm{SO}_{4}^{2-}$ was leached in the first year. The second year, the leaching was relatively similar, however lower in amount, since no $\mathrm{SO}_{4}^{2-}$ was added to irrigation water. The higher the salinity of irrigation waters the higher the correlation between concentrations and leaching fractions. The correlation coefficients between the $\mathrm{SO}_{4}^{2-}$ concentration and leaching fractions were $0.460,0.897$ and 0.942 for $\mathrm{S}_{1}, \mathrm{~S}_{2}$ and $\mathrm{S}_{3}$, respectively. This means that the changes in $\mathrm{SO}_{4}{ }^{2-}$ concentration in the soil was highly correlated with irrigation water salinity. This could be explained by exchange of $\mathrm{SO}_{4}^{2-}$ ions in the soil solid surface by another ion or in other way, by increasing of $\mathrm{SO}_{4}^{2-}$ releasing from the soil surface.

$\mathrm{Cl}^{-}$is the only anion used for salinization of the irrigation water. For almost all salinized treatments $\left(\mathrm{S}_{2}\right.$ and $\left.\mathrm{S}_{3}\right)$ the total mass balance was positive. It means that in salinized treatments less $\mathrm{Cl}^{-}$was leached out with drainage water than the added volume. In $\mathrm{S}_{3}$ treatment, $\mathrm{Cl}^{-}$accumulation decreased with increasing leaching fraction in both years. The high negative correlation coefficient $\left(\mathrm{R}^{2}=0.843-0.869\right)$ between leaching ratio and the $\mathrm{Cl}^{-}$concentration in drainage water were found in $\mathrm{S}_{3}$ salinity level for both years (Figure 2). $\mathrm{No} \mathrm{Cl}^{-}$ accumulation was detected for $\mathrm{S}_{1}$ treatment. $\mathrm{Cl}^{-}$is leached easily from the soil and moves with the same speed as soil water in the coarse soil (Öztürk \& Özkan 2002).

In all treatments, the SMBs of $\mathrm{HCO}_{3}^{-}$were positive. In the irrigations for both years there was a determined accumulation of $\mathrm{HCO}_{3}^{-}$, although its amount was not high. Even though the tap water was the only source for $\mathrm{HCO}_{3}^{-}$(i.e. bicarbonate was not one of the added salinity constituent to the irrigation water) it was not easily leached out from the profile. The correlation was higher in the second year $(0.92$ for $\mathrm{S}_{2}$, and 0.76 for $\mathrm{S}_{3}$ treatments) (Figure 2).

\subsection{SMB for cations}

The major cations in the soil, $\mathrm{Ca}^{2+}, \mathrm{Mg}^{2+}$, and $\mathrm{Na}^{+}$, were taken into account for the salt mass balance calculations. The $\mathrm{Ca}^{2+}$ concentrations of the soil profile increased with saline water irrigation $\left(\mathrm{S}_{2}\right.$ and $\mathrm{S}_{3}$ ) (Figure 3) but did not change considerably with leaching fraction. In $\mathrm{S}_{1}$ treatment, in which tap water was used for irrigation, low amount of $\mathrm{Ca}^{2+}$ leached from the soil profile. Increasing the $\mathrm{Ca}^{2+}$ concentrations in irrigation water caused the accumulation of $\mathrm{Ca}^{2+}$ in the profile, i.e. positive salt balance. The correlation coefficients between the LF and mass concentrations were low and so 
2010
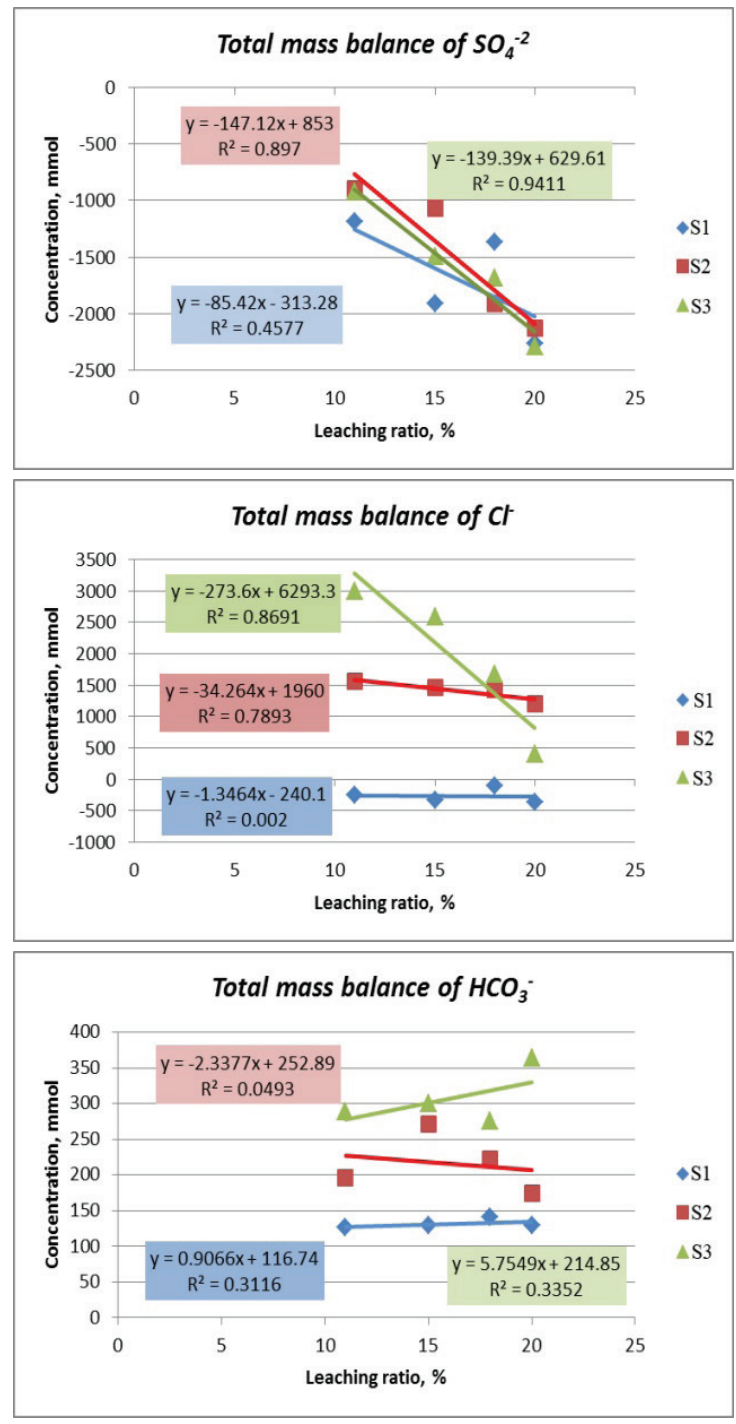

2011
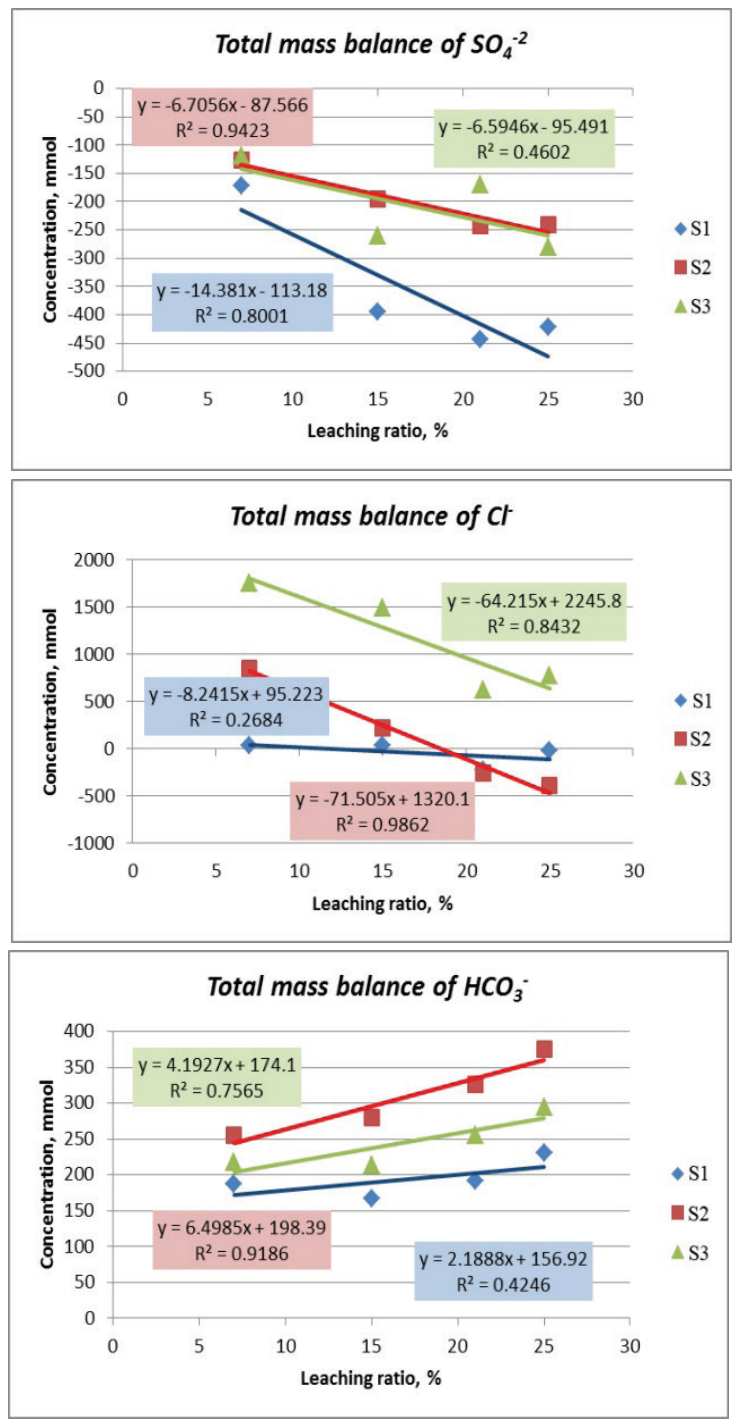

Figure 2- Total mass balances of some major anions related to the accrued leaching ratios, for the first year (2010) and the second year (2011) experiments

Şekil 2- Birinci yıl (2010) ve ikinci yıl (2011) denemeleri icin bazı anyonların, gerçekleşen yıkama oranlarına bağll olarak toplam tuz dengesi değerleri

the relationship was not significant. Results of the experiments done by Islam (1993) revealed that while the exchangeable $\mathrm{Ca}^{2+}$ increased, the exchangeable $\mathrm{Mg}^{2+}$ and $\mathrm{Na}^{+}$decreased in the soil when fresh river water is used, but $\mathrm{Ca}^{2+}$ and
$\mathrm{Mg}^{2+}$ increased more remarkably and those of exchangeable $\mathrm{Na}^{+}$and total exchangeable cations in soil decreased more sharply, when saline drainage water is used for leaching. 
2010
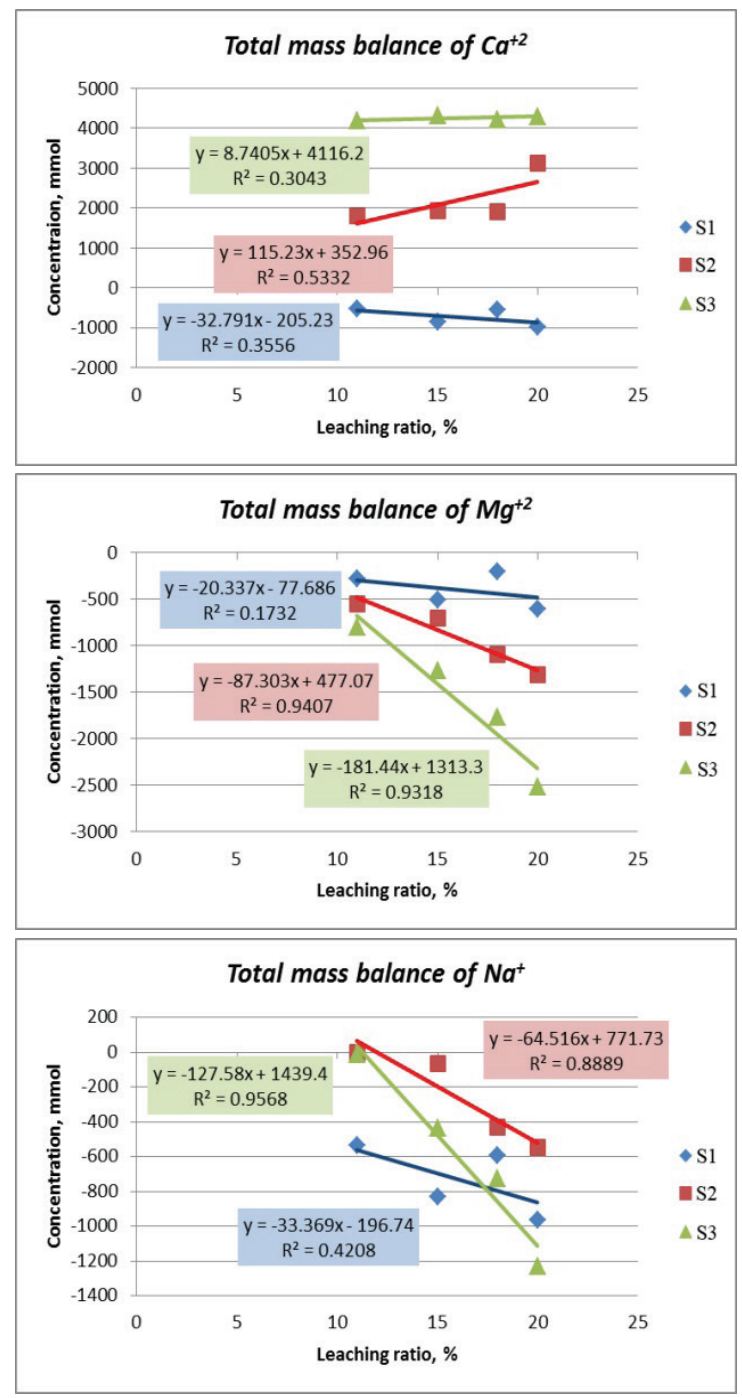

2011
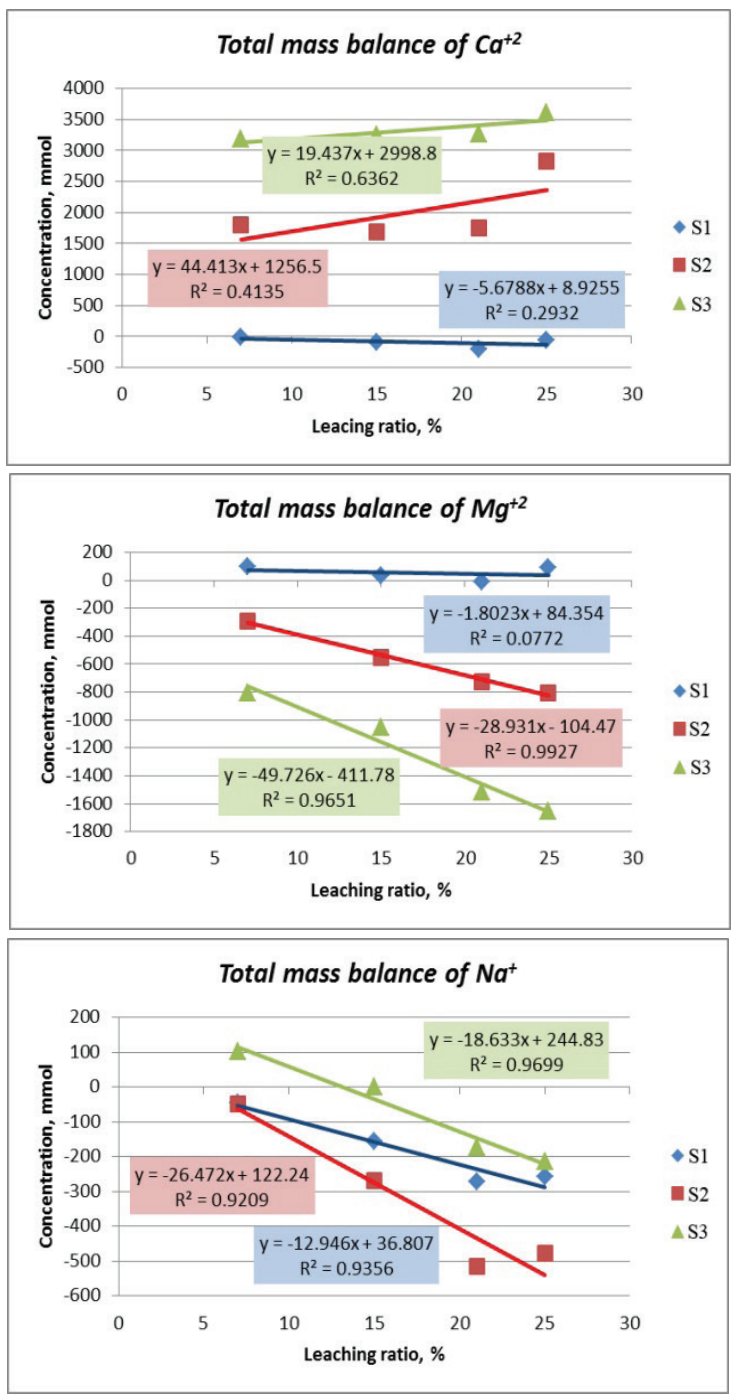

Figure 3- Total mass balances of some major cations related to the accrued leaching ratios, for the first year (2010) and the second year (2011) experiments

Şekil 3- Birinci yıl (2010) ve ikinci yıl (2011) denemeleri icin bazı katyonların, gerçekleşen yıkama oranlarına bağll olarak toplam tuz dengesi değerleri

The total mass concentration of $\mathrm{Mg}^{2+}$ was negative for almost all treatments, which means that the $\mathrm{Mg}^{2+}$ in the soil was leached out during irrigation with different LFs. This was expected since no $\mathrm{Mg}^{2+}$ was added to the irrigation water or to the soil and the other cations, especially $\mathrm{Ca}^{2+}$, in the salinized irrigation water replaced the soil adsorption surfaces and removed them (Kijne at al 1998). The higher the LF, the higher the salinity level and the more the $\mathrm{Mg}^{2+}$ leached. The only exception was the little $\mathrm{Mg}^{2+}$ 
accumulation in the $\mathrm{S}_{1}$ level during the second year. The high correlation coefficients $\left(\mathrm{R}^{2}=0.94,0.93\right.$ and $0.99,0.95$ for $\mathrm{S}_{2}$ and $\mathrm{S}_{3}$ treatments for both years, respectively) between the $\mathrm{Mg}^{2+}$ concentration and leaching ratio are found on the $\mathrm{S}_{2}$ and $\mathrm{S}_{3}$ treatments.

The net $\mathrm{Na}^{+}$leaching from the soil profile was determined for all the salinity levels and LF for both years. The increased LF caused the increased leaching of the $\mathrm{Na}^{+}$. This is probably because of the adsorbed $\mathrm{Ca}^{2+}$ and the released $\mathrm{Na}^{+}$in the soil exchange surfaces. The correlation coefficients between the $\mathrm{Na}^{+}$concentration and leaching ratios are $0.421,0.897$ and 0.957 in the first year and 0.936, 0.921 and 0.970 in the second year for $\mathrm{S}_{1}, \mathrm{~S}_{2}$ and $\mathrm{S}_{3}$, respectively. Related to the cation intercourse, Siczek et al (2008) reported that the leaching of cations is dependent on the concentrations of other cations in the soil solution. For example, Jalali \& Rowell (2003) reported that the increase of potassium would result with the increase of $\mathrm{Ca}^{2+}$ due to the ability of calcium ions. Because calcium ions can displace potassium ions from the exchange pools into the solution.

\section{Conclusions}

Salt mass concentration in the soil profile generally varies with the irrigation practices. Irrigation water salinity is the major factor for this variation. The salts coming with the irrigation water are washed out with the leaching fraction depending on the irrigation water amount. In our column experiments, $\mathrm{SO}_{4}{ }^{2-}$ was washed out relatively easier than the other anions such as $\mathrm{Cl}^{-}$, and $\mathrm{HCO}_{3}^{-}$ . This is a relative comparison, because the initial concentration of $\mathrm{SO}_{4}^{2-}$ was very low and no $\mathrm{SO}_{4}{ }^{2-}$ was added by irrigation and, therefore, its leaching was very effective. Although chloride is known by its high mobility in the soil compared to other anions, when an excess amount of it is added to the soil by irrigation, it can be accumulated for a while. The addition of $\mathrm{Ca}^{2+}$ together with $\mathrm{Na}^{+}$by irrigation water causes the accumulation of $\mathrm{Ca}^{2+}$ and the washing out of other cations, e.g. $\mathrm{Mg}^{2+}$ and $\mathrm{Na}^{+}$. This is because of the preferences of the soil adsorption surfaces. SMB should be taken into account for soil reclamation and management of arid and semiarid soils. It gives a very general but simple conclusion.

\section{References}

Al-Absi K M, Al-Nasir F M \& Mahadeen A Y (2009). Mineral content of three olive cultivars irrigated with treated industrial wastewater. Agricultural Water Management 96: 616-626

Corwin D L, Rhoades, J.D. \& Simunek J (2007). Leaching requirement for soil salinity control: Steady-state versus transient models. Agricultural Water Management 90: 165-180

Hutson A C \& Ickert R A (2012). Sustainability in water supply. In: World Environmental and Water Resources Congress 2012: Crossing Boundaries, ASCE, pp. 2856-2872

Islam Md Z (1993). Leaching Effect of Saline Drainage Water on Exchangeable Cations in Soil. Journal of Irrigation, Engineering and Rural Planning 24: 4-18

Jalali M \& Rowell D L (2003). The role of calcite and gypsum in the leaching of potassium in a sandy soil. Experimental Agriculture 39: 379-394

Kijne J W, Prathapar S A, Wopereis M C S \& Sahrawat K L (1998). How to Manage Salinity in Irrigated Lands: A Selective Review with Particular Reference to Irrigation in Developing Countries. SWIM Paper 2. Colombo, Sri Lanka: International Irrigation Management Institute, Sri Lanka

Oster J D, Letey J, Vaughan P, Wu L \& Qadir M (2012). Comparison of transient state models that include salinity and matric stress effects on plant yield. Agricultural Water Management 103:167-175

Öztürk H S \& Özkan İ (2002). Solute movement in large soil columns during different ponded infiltration. Australian Journal of Agricultural Research 53: 183189

Rhoades J D (1974). Drainage for salinity control. In: van Schilfgaarde J (Ed.), Drainage for Agriculture. Agronomy Monograph No. 17. SSSA, Madison, WI, pp. 433-461

Rhoades J D \& Loveday J (1990). Salinity in irrigated agriculture. In: Stewart B A \& Nielsen D R (Eds.), Irrigation of Agricultural Crops. Agronomy Monograph No. 30. SSSA, Madison, WI, pp. 10891142

Richards L A (1954). Diagnosis and Improvement of Saline and Alkali Soils. U.S. Dept. Agriculture, Handbook 60. U.S. Government Printing Office, Washington 
Siczek A, Kotowska U, Lipiec J \& Nosalewiczl A (2008). Leaching of potassium, magnesium, manganese and iron in relation to porosity of tilled and orchard loamy soil. Acta Agriculturae Scandinavica Section B-Soil and Plant Science 58: 60-65

Skaggs T H, Poss J A, Shouse P J \& Grieve C M (2006). Irrigating forage crops with saline waters: 1 . Volumetric lysimeter studies. Vadose Zone Journal 5: 815-823

Yıldız M \& Terzi H (2011). Türkiye'de Ekimi Yapılan Bazı Arpa Çeşitlerinde Erken Fide Evresi Tuz Toleransının Belirlenmesi. Tartm Bilimleri Dergisi 17(1): 1-9
Yurtseven E, Avcı S, Öztürk H S, Altınok S \& Selenay M F (2012). Drainage water quality management: impact of different irrigation water quality and leaching fractions on drainage water salinity. In: Proceedings of the VIII. International Soil Science Congress "Land Degradation and Challenges in Sustainable Soil Management” 15-17 May, İzmir, Turkey

Zhong H (2011). Salt mass balance study and plant physiological responses for an enhanced salt phytoremediation system. Master Thesis (Unpublished), Waterloo University, Ontario, Canada 